\title{
Bacterial Spot of Tomato and Pepper on Four East Caribbean Islands: Races, Their Abundance, Distribution, Aggressiveness, and Prospects for Control
}

\author{
Leonard W. O'Garro, Microbial Pathogenicity Research Group, Department of Biological and Chemical Sciences, \\ University of the West Indies, Cave Hill Campus, P.O. Box 64, Bridgetown, Barbados
}

\begin{abstract}
O'Garro, L. W. 1998. Bacterial spot of tomato and pepper on four East Caribbean islands: Races, their abundance, distribution, aggressiveness, and prospects for control. Plant Dis. 82:864-870.

A total of 5,134 strains of Xanthomonas campestris pv. vesicatoria obtained from diseased pepper and tomato fruits at 22 diverse locations on the East Caribbean islands of Antigua, St. Christopher, St. Lucia, and Grenada were assessed for pathogenicity, taxonomic group phenotypes, and sensitivity to copper, zinc, and streptomycin. Altogether, 15 known races, namely T1, T2, P0T1, P0T2, P1T1, P1T2, P2T1, P2T2, P3T1, P3T2, P4T2, P5T2, P5T3, P6T2, and P6T3, were detected. Races T1, P0T1, P0T2, P1T2, P2T1, and P3T1 were common to all islands except St. Lucia. St. Lucia had races P2T2, P3T2, P4T2, and P6T2 in common with Grenada and two races each from among the four pathotypes in common with Antigua and St. Lucia. Races T1, P1T2, P3T1, and P3T2 were the most abundant strains of the bacterium in Antigua, whereas the two latter pathotypes, as well as races P0T1 and P2T1, were among the most prevalent strains in St. Christopher. In contrast, races P6T2 and P5T2 predominated in St. Lucia, and P6T2, P1T2, and P3T2 were the abundant pathotypes in Grenada. Generally, the largest bacterial spot fruit lesions were associated with the predominant races on each island, and the smallest lesions were generally linked to races capable of overcoming gene Bs2. Only these latter races were similar to group B strains of X. campestris pv. vesicatoria with respect to the presence of $\beta$-protein in their cellular protein profiles, ability to hydrolyze starch, and inability to oxidize cis-aconitate. Other race types tested resembled group A strains of the bacterium in their ability to utilize cis-aconitate, inability to hydrolyze starch and pectate, and the presence of the $\alpha$-protein in profiles of cellular proteins. Copper-resistant strains of $X$. campestris pv. vesicatoria constitute 8.7 to $10.6 \%$ of the pathogen collections from Antigua and St. Christopher and 44.4 and $66.7 \%$ of pathotypes from St. Lucia and Grenada, respectively. Almost all strains were sensitive to zinc. Streptomycin resistance was observed among $62 \%$ of the strains in St. Christopher and Grenada and 62.8 to $83.6 \%$ of those in Antigua and St. Lucia.
\end{abstract}

Bacterial spot caused by Xanthomonas campestris pv. vesicatoria (proposed: Xanthomonas axonopodis pv. vesicatoria) is an important disease of pepper (Capsicum annuum L.) and tomato (Lycopersicon esculentum Mill.) on the anglophone eastern Caribbean islands. Efforts to increase production of these crops have been limited mainly by difficulties encountered in controlling the disease. Consequently, pepper and tomato fruits are often imported to the islands, notably during the period coincident with the annual rainy season, in order to satisfy local demand.

Studies on the epidemiology of bacterial spot have mainly focused on variations in $X$. campestris pv. vesicatoria populations with respect to pathogenicity $(4,7-10,12$, 14,15,17-19,25), sensitivity to chemical control agents $(1,6,16,20,24)$, and more

Corresponding author: L. W. O'Garro

E-mail: logarro@uwichill.edu.bb

Accepted for publication 17 April 1998.

Publication no. D-1998-0520-04R

(C) 1998 The American Phytopathological Society recently, the extent of DNA homology (4). Pathogenic variation in populations of the bacterium is usually expressed in terms of the existence of physiological races, which are distinguished on the basis of virulence on specific pepper and tomato genotypes $(9,10,15,16)$. Races T1, T2, and T3, all of which are pathogenic on tomato but not pepper, and races $\mathrm{P} 0, \mathrm{P} 1, \mathrm{P} 2, \mathrm{P} 3, \mathrm{P} 4, \mathrm{P} 5$, and $\mathrm{P} 6$, each capable of infecting pepper but not tomato, as well as races virulent on both pepper and tomato, have been reported $(4,8,10,17,18,25)$. Tomato cultivars Hawaii 7998 and Hawaii 7981 provide resistance to races $\mathrm{T} 1$ and $\mathrm{T} 3$, respectively, but are susceptible to race T2 $(10,17,22)$. In contrast, single dominant genes, namely $B s 1, B s 2$, and $B s 3$, control resistance to bacterial spot of pepper. Gene $B s l$ restricts races $\mathrm{P} 0, \mathrm{P} 2$, and $\mathrm{P} 5$, and gene $B s 2$ confers resistance to $\mathrm{P} 0, \mathrm{P} 1, \mathrm{P} 2$, and $\mathrm{P} 3$. Races $\mathrm{P} 0$, $\mathrm{P} 1$, and $\mathrm{P} 4$ are restricted by gene $B s 3$. In an earlier study of the geographical distribution of races of $X$. campestris pv. vesicatoria, it was suggested that races might be restricted to specific locations (7). There are, however, recent reports on changes in race structure of populations of the bacterium. In Florida, race T3 has been recently detected for the first time (10), and race $\mathrm{P} 1$ replaced a pepper-tomato race as the most prevalent pathotype on pepper (19). Races P4 and P5 appeared also for the first time on pepper in the southeastern United States (12).

Although the race structure of various populations of $X$. campestris pv. vesicatoria has been studied extensively, little information is available on the aggressiveness or virulence of each prevailing race. Recently, O'Garro and Tudor (18) reported that bacterial spot lesions on pepper and tomato fruits were mostly associated with pepper race 1 strains and tomato race 1 strains, respectively. The lesions caused by strains of these two races were significantly larger than those associated with other races isolated in Barbados.

Sprays of copper bactericides, in conjunction with maneb, zineb, and mancozeb or streptomycin, are often used in attempts to control bacterial spot of pepper and tomato. These chemicals have given variable levels of control; and when they were used frequently for prolonged periods, resistance in field populations of $X$. campestris pv. vesicatoria to copper $(1,22,25)$, zinc $(1,24)$, and streptomycin (16) has appeared. In some strains of the bacterium, resistance to copper and streptomycin is mediated by plasmid-borne genes $(2,20,24)$.

The extent of DNA homology between strains of $X$. campestris pv. vesicatoria has been recently used as the basis for proposing the existence of two genetically distinct groups, namely $\mathrm{A}$ and $\mathrm{B}$, of the bacterium $(1,2,23)$. These groups share less than $50 \%$ DNA homology and differ also in a number of other characteristics. Generally, group B strains hydrolyze starch and pectate but do not oxidize cis-aconitate, which is oxidized by group A strains $(4,5)$. In contrast, group A strains are not pectolytic or amylolytic. The groups also differ in the presence of proteins of sizes 32 to $35 \mathrm{kDa}$ ( $\alpha$-protein) and 25 to $27 \mathrm{kDa}$ ( $\beta$-protein) in the total cellular protein profiles of $\mathrm{A}$ and B group strains respectively $(3,4)$. Groups $\mathrm{A}$ and $\mathrm{B}$ are also differentiated by specific monoclonal antibodies and the relative amounts of the cellular fatty acid 15:0 anteiso, which is greater in group A strains (4). A recent study reported the existence of both groups in North America, South America, Australia, Europe, and Africa; whereas only group A strains were detected in a bacterial collection from Taiwan (4). 
Barbados is the only island in the eastern Caribbean where bacterial spot of pepper and tomato has been reported $(18,25)$. The present study extends recent investigations on bacterial spot in the Caribbean $(5,18,25)$ to Antigua, St. Christopher, St. Lucia, and Grenada and reports on the prevalence and virulence of $X$. campestris pv. vesicatoria races as well as phenotypic characteristics associated with $\mathrm{A}$ and $\mathrm{B}$ groups of the bacterium. The sensitivity of the bacterium to chemical control agents was also investigated.

\section{MATERIALS AND METHODS}

Determination of bacterial spot severity. Bacterial spot-infested pepper and tomato farms on Antigua, St. Christopher, St. Lucia, and Grenada were selected for this study. Fruits were obtained at harvest from a random sample of 0.01 to $0.05 \%$ of plants of each crop. The areas of typical bacterial spot lesions on each fruit were measured and used to determine disease severity as previously described (18). Eighteen tomato farms were surveyed: nine from St. Lucia, one from St. Christopher, and four each from Antigua and Grenada. Three pepper farms from St. Lucia and one from Antigua were also sampled. The survey was conducted in 1993 to 1994 during the annual rainy season, which generally extends from June to November.

Isolation of pathogen. Fruits were washed in tap water to remove soil debris and then surface-disinfested by dipping sequentially in ethanol $(95 \%)$ and sodium hypochlorite $(1.25 \%)$ for $5 \mathrm{~s}$ each, and finally rinsed in sterile distilled water. Fully matured bacterial spot lesions, characterized by black or brown surfaces, were excised and each homogenized in sterile distilled water $(100 \mu \mathrm{l})$ using a sterile mortar and pestle. Loopfuls of homogenates were then streaked onto nutrient agar (Difco Laboratories, Detroit, $\mathrm{MI}$ ) and incubated at 28 to $30^{\circ} \mathrm{C}$ for 3 to 5 days to obtain colonies of $X$. campestris pv. vesicatoria. A random sample of three colonies of the presumptive bacterium from each lesion was selected and retained (18).

Differential pepper and tomato genotypes. Tomato cultivars Walter, Hawaii 7998, and Hawaii 7981, and near-isogenic pepper cultivars Early Calwonder (ECW), ECW10R, ECW20R, and ECW30R were used as differential hosts for strains of $X$. campestris pv. vesicatoria. Pepper cultivar ECW and tomato cultivar Walter carry no known resistance genes for bacterial spot (9,10,17). Cultivars ECW10R, ECW20R, and ECW30R contain genes $B s 1, B s 2$, and $B s 3$ respectively $(9,17)$. Plants were grown for 4 weeks in sterile potting compost under conditions previously described $(18,25)$ before inoculation.

Identification of pathogen and race types. A sample of 25 putative strains of $X$. campestris pv. vesicatoria chosen at random from those isolated from each island surveyed was subjected to the following physiological and biochemical tests in duplicate: cell morphology; Gram reaction, presence of catalase, oxidase, and nitrate reductase; acid production from glucose, arabinose, and mannose; utilization of asparagine as sole source of carbon and nitrogen; and xanthomonadin pigment production using standard bacteriological methods (21). Identification was confirmed by testing each strain for pathogenicity on one plant each of Walter and ECW. Leaves of test plants were sprayed with a bacterial suspension $\left(10^{6}\right.$ cells $\left.\mathrm{ml}^{-1}\right)$, and plants were observed for symptoms for 14 days $(18,25)$.

$X$. campestris pv. vesicatoria was differentiated into races as outlined $(4,10,14,17)$ on the basis of hypersensitive or susceptible reaction in leaves of Walter, Hawaii 7998, Hawaii 7981, ECW, ECW10R, ECW20R, and ECW30R. Bacterial cells $\left(10^{8}\right.$ to $\left.10^{9} \mathrm{ml}^{-1}\right)$ were introduced into the intercellular spaces of the two youngest fully expanded leaves of each test plant $(9,18)$. There were two replicate inoculations, and three strains of the bacterium from each lesion were tested for race type. The experiment was conducted twice.

Determination of A and B groups' phenotypic characteristics. $X$. campestris pv. vesicatoria was tested for the presence of the $\alpha$ - or $\beta$-protein in extracts of whole cell protein and for the ability to oxidize cis-aconitate and hydrolyze starch and pectate. Whole cell proteins were extracted from 1,500 $\mu$ l of bacterial suspension $(5 \times$ $10^{8}$ cells $\mathrm{ml}^{-1}$ ) and prepared for sodium dodecyl sulfate polyacrylamide gel electrophoresis (SDS-PAGE) (3). Protein samples $(20 \mu \mathrm{l})$ were loaded onto a $12.5 \%$ Excel gel SDS homogenous polyacrylamide gel (Pharmacia, Uppsala, Sweden) and separated under a current of 25 to 30 $\mathrm{mA}$ using a Multiphor electrophoresis unit (Pharmacia). Fractionated proteins were visualized by staining with silver (Sigma Chemical Co., St. Louis, MO), and the $\alpha$ and $\beta$-proteins in the electrophoregram were identified by their characteristic sizes of $35 \mathrm{kDa}$ and $26 \mathrm{kDa}$, respectively (3). A random collection of 50 strains of $X$. campestris pv. vesicatoria made up of samples of the bacterium from each island was tested. The experiment was conducted twice.

The ability of the bacterium to hydrolyze starch and pectate was tested by placing droplets $(20 \mu \mathrm{l})$ of bacterial suspensions $\left(5 \times 10^{8}\right.$ cells $\left.\mathrm{ml}^{-1}\right)$ onto nutrient agar amended with $0.1 \%$ starch and $0.5 \%$ pectate, respectively, and incubating cultures at 28 to $30^{\circ} \mathrm{C}$ for 3 to 5 days. Clear zones appearing around bacterial colonies on starch medium after flooding with Lugol iodine for $30 \mathrm{~min}$ indicate starch hydrolysis. Pectate hydrolysis was detected by clearing zones after treatment with solutions of cetyltrimethylammonium bromide $(0.1 \%)$ for $5 \mathrm{~min}$ and ruthenium red $(0.1 \%)$ for $20 \mathrm{~min}$. Three strains of $X$. campestris pv. vesicatoria from each lesion were assessed for ability to hydrolyze starch, and the random sample of 50 strains mentioned above was tested for ability to hydrolyze pectate. Each test was replicated three times, and the experiment was conducted twice.

Plates of Dye's medium (20) amended with $c i$-aconitate $(0.5 \%)$ as the sole source of carbon were spotted with $20-\mu \mathrm{l}$ droplets of bacterial suspensions $\left(5 \times 10^{8}\right.$ cells $\left.\mathrm{ml}^{-1}\right)$. Evidence of bacterial growth after 5 days incubation at 28 to $30^{\circ} \mathrm{C}$ was taken as a positive test of $c i$-aconitate utilization by $X$. campestris pv. vesicatoria. Test strains were the random samples of 50 strains of the bacterium referred to above. Each test for $c i s$-aconitate utilization was replicated three times, and the experiment was conducted twice.

Sensitivity of $X$. campestris pv. vesicatoria to bactericides. Aliquots $(100 \mu \mathrm{l})$ of bacterial suspensions $\left(10^{8}\right.$ cells $\left.\mathrm{ml}^{-1}\right)$ were spread onto nutrient agar amended with $200 \mu \mathrm{g} \mathrm{ml}^{-1} \mathrm{CuSO}_{4} \cdot 5 \mathrm{H}_{2} \mathrm{O}$ (AnalaR), 100 $\mu \mathrm{g} \mathrm{ml}^{-1} \mathrm{ZnSO}_{4} \cdot 7 \mathrm{H}_{2} \mathrm{O}$ (AnalaR), or $250 \mu \mathrm{g}$ $\mathrm{ml}^{-1}$ streptomycin sulfate (Sigma) and then incubated for 5 to 6 days at 28 to $30^{\circ} \mathrm{C}$ to determine viability of $X$. campestris $\mathrm{pv}$. vesicatoria. Strains of the bacterium producing confluent growth were considered resistant to copper, zinc, or streptomycin, and those that failed to grow were considered sensitive. Three strains of the bacterium from each lesion were tested, and each test was replicated three times. The experiment was performed twice.

\section{RESULTS}

Isolation and identification of pathogen. All of the 25 strains of the presumptive pathogen tested for xanthomonadins yielded yellow spots with an average $R_{\mathrm{f}}$ value of 0.45 on thin-layer, silica gel chromatography plates. The strains were also yellow, rod-shaped, gram-negative, oxidase-negative, and catalase-positive. Strains utilized glucose, arabinose, and mannose for acid production. None of the strains reduced nitrates or utilized asparagine as the sole source of carbon and nitrogen, and all induced typical bacterial spot symptoms on ECW and/or Walter.

Bacterial spot severity and race classification. Bacterial spot fruit infection occurred on all pepper and tomato farms surveyed. The tomato cultivars Heatwave and Heatmaster (Peto Seed Co., Saticoy, CA) and the pepper cultivar King Arthur (Peto) were represented in the survey. Lesion sizes varied widely on tomato fruits and ranged from 0.5 to $2.3 \mathrm{~mm}^{2}$ in Antigua, 1.0 to $1.8 \mathrm{~mm}^{2}$ in St. Christopher, 0.2 to $2.5 \mathrm{~mm}^{2}$ in St. Lucia, and 0.5 to 2.3 $\mathrm{mm}^{2}$ in Grenada. Pepper fruit lesions also varied in size; typical areas for Antigua and St. Lucia were 0.5 to $1.0 \mathrm{~mm}^{2}$. Mean surface areas of tomato fruits covered by bacterial spot lesions were $1.5 \mathrm{~mm}^{2}$ each in 
Antigua and St. Christopher and $0.8 \mathrm{~mm}^{2}$ and $1.3 \mathrm{~mm}^{2}$ in St. Lucia and Grenada, respectively. Lesions on pepper fruits were $0.8 \mathrm{~mm}^{2}$ each in Antigua and St. Lucia.

The race structure of $X$. campestris pv. vesicatoria populations varied with each island (Table 1). Seven races of the bacterium were detected in St. Lucia, 10 races each in Antigua and Grenada, and 9 races in St. Christopher. Races T1, P0T1, P0T2, P1T2, P2T1, and P3T1 were detected in all islands except St. Lucia. St. Lucia had races $\mathrm{P} 2 \mathrm{~T} 2$, $\mathrm{P} 5 \mathrm{~T} 2, \mathrm{P} 4 \mathrm{~T} 2$, and $\mathrm{P} 6 \mathrm{~T} 2$ in common with Grenada and two races each from among the four pathotypes in common with Antigua and St. Christopher. Races P5T2, P5T3, and P6T3 were detected in St. Lucia, and race T2 was observed in Antigua. Races P3T2, P3T1, P1T2, and T1 were the most prevalent pathotypes in Antigua, where they constituted 12.2 to $22.7 \%$ of the strains. In addition to races $\mathrm{P} 0 \mathrm{~T} 1$ and $\mathrm{P} 2 \mathrm{~T} 1$, races $\mathrm{P} 3 \mathrm{~T} 1$ and P3T2 were also among the most abundant strains detected in St. Christopher. In contrast, races P5T2 and P6T2 accounted for over $85 \%$ of strains from St. Lucia; whereas races P1T2 and P6T2 were of highest frequency in Grenada, where they comprised 15.5 to $22.4 \%$ of the strains tested.

With the exception of St. Christopher, where only one farm was surveyed, the distribution of races of $X$. campestris pv. vesicatoria varied also with location of farms on each island (Table 2 and Fig. 1). In Antigua, races P0T1, P1T1, and P6T2 were each detected at single locations only; whereas race $\mathrm{P} 3 \mathrm{~T} 2$ was present along with four to six other race types at three locations and with race P3T1 at one location. Two locations in St. Lucia were infested with race P6T2 only, which was also present at eight other locations, most often with races $\mathrm{P} 5 \mathrm{~T} 2$ and $\mathrm{P} 2 \mathrm{~T} 2$, followed by races P6T3, P5T3, P3T2, and P3T2. The latter race was detected at one St. Lucian location only. In contrast, locations 3 and 4 in Grenada were infested with seven and six race types, respectively; whereas two to three races from among T1, P0T1, P0T2, $\mathrm{P} 1 \mathrm{~T} 2$, and P2T1 were detected at the two remaining Grenadian locations. Races P4T2 and P6T2 were obtained at one location only in Grenada.
The extent of pepper and/or tomato fruit damage associated with each race of $X$. campestris pv. vesicatoria detected is shown also in Table 2. Single races, as well as mixtures of two to three races, notably in St. Lucia, were isolated from tomato fruit lesions. Many of these lesions were also associated with xanthomonads of unknown affinity. Bacterial spot fruit lesions observed on each Antiguan farm were similar in size, except those associated with race $\mathrm{P} 3 \mathrm{~T} 2$ only at location 1 and race P0T2 only at location 2, which were significantly more extensive than lesions associated with all other races at the respective locations. In St. Christopher, bacterial spot lesions were also of similar size except those associated with race $\mathrm{P} 2 \mathrm{~T} 1$, which were distinctly larger than lesions from which races P0T2 and P1T1 were obtained. Lesions differing significantly in size were observed on St. Lucia at locations 4,9 , and 10 only, and in all cases the largest lesions were associated with race P6T2 only or when combined with race $\mathrm{P} 2 \mathrm{~T} 2$, P5T2, or P5T3 and P6T3. Lesions induced by $X$. campestris pv. vesicatoria in Grenada at locations 1 and 2 were of similar size, but those yielding races P2T1 and $\mathrm{P} 2 \mathrm{~T} 2$ at locations 3 and races $\mathrm{P} 1 \mathrm{~T} 2, \mathrm{P} 3 \mathrm{~T} 2$, $\mathrm{P} 4 \mathrm{~T} 2, \mathrm{P} 6 \mathrm{~T} 2$, and a mixture of P6T2 and $\mathrm{P} 2 \mathrm{~T} 2$ at location 4 were significantly more extensive than lesions associated with at least two to seven other races detected at the respective locations.

Taxonomic group characteristics. All of the 50 strains of $X$. campestris pv. vesicatoria tested for protein profiles contained the $\alpha$ - or $\beta$-proteins. Thirty of these strains, including six representatives each of races P4T2, P5T2, P5T3, P6T2, and P6T3, produced the $\beta$-protein; whereas the $\alpha$-protein was detected in cell extracts of at least two races each of T1, P0T1, P0T2, P1T1, P1T2, P2T2, P3T1, and P3T2. None of the 50 strains tested hydrolyzed pectate, but strains containing the $\beta$-protein were positive for starch hydrolysis. Altogether, 39.9, $28.3,72.9$, and $10.9 \%$ of all strains from Antigua, St. Christopher, St. Lucia, and Grenada, respectively, hydrolyzed starch. These starch-hydrolyzing xanthomonads were obtained in excess of $70 \%$ of strains from each location in St. Lucia and in amounts ranging from 55.6 to $66.7 \%$ and
26.7 to $42.9 \%$ of strains from two locations each on Antigua and Grenada, respectively (Fig. 1).

Response of pathogen to copper, zinc, and streptomycin. The responses of $X$. campestris pv. vesicatoria to copper, zinc, and streptomycin varied considerably from island to island (Table 3). Copper-resistant strains of $X$. campestris pv. vesicatoria constituted less than $11 \%$ of each collection from Antigua and St. Christopher and 41.4 to $66.7 \%$ from St. Lucia and Grenada. Many pathogen strains were sensitive to zinc, however, $62.3 \%$ each in St. Christopher and Grenada and $68.2 \%$ in Antigua, and $83.6 \%$ in St. Lucia were resistant to streptomycin (Table 3).

The distribution of strains of $X$. campestris pv. vesicatoria resistant to copper or streptomycin also varied within each island (Fig. 1). Copper-resistant strains detected in Antigua were from four of five locations and made up 7.4 to $22.2 \%$ of the pathogen collection. In St. Lucia, almost all strains of the bacterium obtained from locations $1,3,4,7,9$, and 12 were resistant to copper; whereas all those from location 5 were sensitive. At the other locations in St. Lucia, 40.0 to $60.0 \%$ of the strains tested were copper-resistant. In contrast, all copper-resistant strains detected in Grenada were from one of four locations surveyed. All strains of the bacterium obtained from locations 1 and 4 in Antigua and locations 1 and 2 in Grenada were streptomycin-sensitive. The percentages of strains resistant to streptomycin at other locations were 33.3 and $60.0 \%$ in Grenada and Antigua, respectively, and 40.0 to $97.0 \%$ in St. Lucia (Fig. 1).

\section{DISCUSSION}

Until this study, the only systematic surveys of races of $X$. campestris pv. vesicatoria in the eastern Caribbean had been conducted in Barbados $(18,25)$ and Guadeloupe (5). The present study extends investigation of the disease to the other East Caribbean islands of Antigua, St. Christopher, St. Lucia, and Grenada. A total of 15 races of $X$. campestris pv. vesicatoria were detected. Only race P3T2 was common to all islands. Races T1, P0T1, P0T2, P1T2, P2T1, and P3T1 were found on Antigua, St. Christopher, and Grenada.

Table 1. Physiological races of Xanthomonas campestris pv. vesicatoria obtained from pepper and tomato fruits produced on four eastern Caribbean islands

\begin{tabular}{|c|c|c|c|c|c|c|c|c|c|c|c|c|c|c|c|c|c|c|}
\hline \multirow[b]{2}{*}{ Island } & \multirow[b]{2}{*}{ Fruit } & \multirow[b]{2}{*}{ Strains } & \multicolumn{16}{|c|}{ Percentage of strains $^{\mathrm{z}}$} \\
\hline & & & $\mathbf{T 1}$ & $\mathbf{T 2}$ & P0T1 & P0T2 & P1T1 & P1T2 & P2T1 & P2T2 & P3T1 & P3T2 & P4T2 & P5T2 & P5T3 & P6T2 & P6T3 & Unkn. \\
\hline Antigua & $\begin{array}{l}\text { Tomato } \\
\text { and } \\
\text { pepper }\end{array}$ & 985 & 15.2 & 6.1 & 6.0 & 3.0 & 6.1 & 15.2 & 4.5 & $\ldots$ & 12.1 & 22.7 & $\ldots$ & $\cdots$ & $\ldots$ & 6.1 & $\cdots$ & 3.0 \\
\hline St. Christopher & Tomato & 138 & 2.2 & $\ldots$ & 10.9 & 4.3 & 2.2 & 8.7 & 13.0 & 4.3 & 17.4 & 37.0 & $\ldots$ & $\ldots$ & $\ldots$ & $\ldots$ & $\ldots$ & $\ldots$ \\
\hline St. Lucia & $\begin{array}{l}\text { Tomato } \\
\text { and } \\
\text { pepper }\end{array}$ & 2,160 & $\ldots$ & $\ldots$ & $\ldots$ & $\ldots$ & $\ldots$ & $\ldots$ & $\ldots$ & 2.0 & $\ldots$ & 2.1 & 0.8 & 25.1 & 4.3 & 61.5 & 1.7 & 1.7 \\
\hline Grenada & Tomato & 1,740 & 6.9 & $\ldots$ & 9.2 & 6.9 & $\ldots$ & 15.5 & 9.8 & 5.2 & 1.7 & 10.8 & 5.2 & $\ldots$ & $\ldots$ & 22.4 & $\ldots$ & 6.9 \\
\hline
\end{tabular}

z The letters T and PT refer to tomato and pepper-tomato races, respectively; pathotypes that cannot be determined are represented by "unkn." 
Race T2 was detected in Antigua, and races P5T2, P5T3, and P6T3 were found in St. Lucia. In addition to races P3T2 and P3T1, which were the most prevalent pathotypes detected in St. Christopher, races $\mathrm{P} 1 \mathrm{~T} 2$ and $\mathrm{T} 1$ were among the most abundant strains of the bacterium in Antigua. In contrast, races P5T2 and P6T2 were the predominant pathotypes identified in St. Lucia, with P6T2 also common in Grenada. The spectrum of races from St. Lucia was unique and may indicate significant genetic isolation of the pathogen population on this island. There is also the possibility that imported infested pepper and tomato seeds may have influenced this pathogen race structure. Infested seeds have been implicated in the introduction and subsequent emergence of previously undetected pathotypes of $X$. campestris pv. vesicatoria on tomato in Florida (10).

The results of the present study could provide a basis for a bacterial spot control strategy utilizing selective deployment of

Table 2. Mean sizes of tomato and pepper fruit lesions incited by different races of Xanthomonas campestris pv. vesicatoria in the East Caribbean islands of Antigua, St. Christopher, St. Lucia, and Grenada

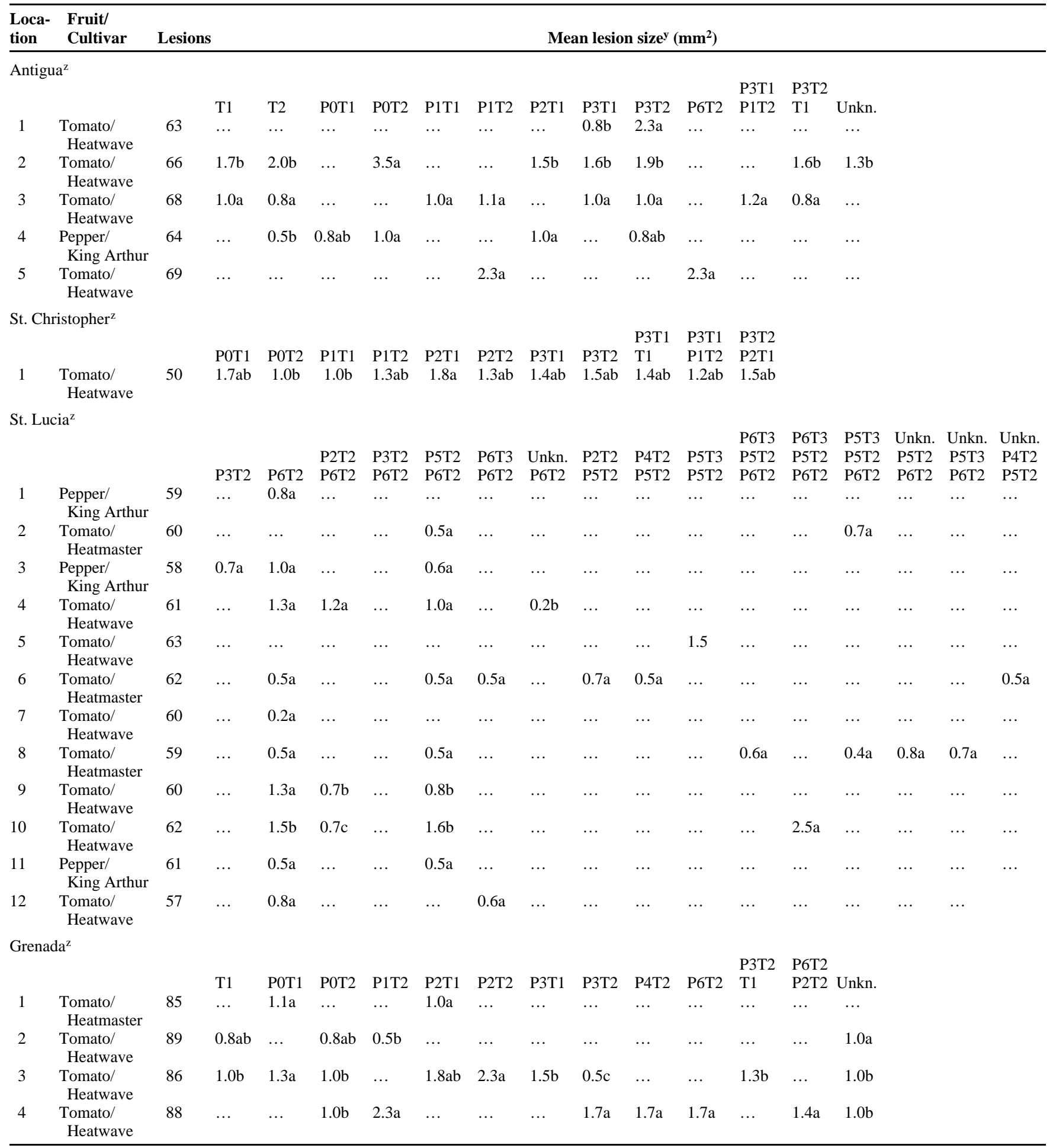

${ }^{y}$ Mean area of lesions in the same row followed by the same letter are not significantly different $(P<0.05)$ based on Tukey's honestly significant difference test.

${ }^{\mathrm{z}}$ The letters T and PT refer to tomato and pepper-tomato races of $X$. campestris pv. vesicatoria, respectively; pathotypes that cannot be determined are represented by "Unkn." 


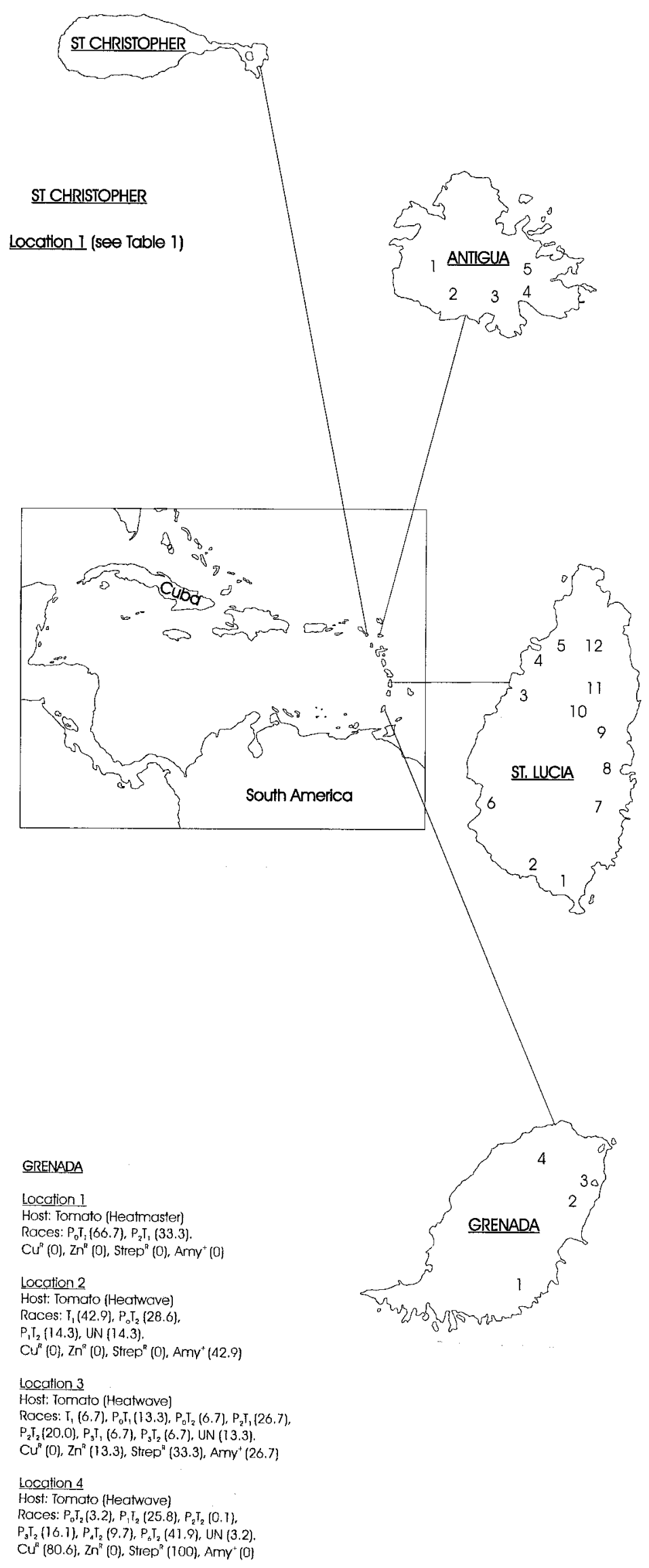

ANTIGUA

Locotion I

Host: Tomato (Heatwave)

Races: $P_{3} T_{1}(50.0), P_{3} T_{2}(50.0)$

$\mathrm{Cu}^{\prime 2}(16.7), \mathrm{Zn}^{n}\left\{0 \mid\right.$, Strep $^{\mathrm{p}}(0), \mathrm{Amy}^{4}(0)$

Location 2

Host: Tomato (Heatwave)

Races: $T_{8}(33.3), T_{2}(3.7), P_{n} T_{2}$ (3.7).

$P_{2} T_{1}(7.4), P_{3} T_{1}(14.8), P_{3} T_{2}(25.9), U N(11.2)$.

$\mathrm{Cu}^{\prime \prime}(7.4), \mathrm{zn}^{2}$ (0), Strep" (100), Amy $(55.6)$

Location 3

Host: Tomato (Heatwove)

Roces: $T_{1}(6.7), T_{2}(13.3) . P_{,} T_{1}(26.7)$

$P_{1} T_{3}(33.3), P_{3} T_{1}(6.7), P_{3} T_{2}(13.3)$.

$\mathrm{Cu}^{R}(0), Z \mathrm{n}^{\mathrm{P}}(0), \mathrm{Strep}^{\mathrm{n}}$ (60), Amy' (60)

Location 4

Host: Pepper (King Arthur)

Roces: $T_{2}(11,1) P_{1} T_{1}(33.3)$

$\left.P_{0} T_{2}(11.1), P_{2} T_{2}, 17.1\right\}, P_{3} I_{2}\{33.3)$.

$\mathrm{Cu}^{2}(22.2), 2 n^{n}(0)$, Strep $p^{8}(0), \mathrm{Amy}^{+}(66.7)$

Location 5

Host: Tomato (Heatwave)

Races: $P_{1} T_{2}(55.6), P_{3} T_{2}(44.4)$

$\mathrm{Cu}^{\mathrm{p}}(22,2), \mathrm{Zn}^{2}(0), \mathrm{Strep}^{\mathrm{R}}$ (100), Amy (0)

\section{ST. LUCA}

Location 1

Host: Pepper (King Arthur)

Race: $P_{6} T_{2}(100.0)$.

$\mathrm{Cu}^{8}(100), \mathrm{Zn}^{n}(0)$, Strep $^{R}(75), \mathrm{Amy}^{+}(56.3)$

Location 2

Host: Tomato (Heatmaster)

Races: $P_{5} T_{2}(40.0), P_{5} T_{3}(4.0), P_{6} T_{2}(56.0)$.

$\mathrm{Cu}^{2}(55.6), \mathrm{Zn}^{\mathrm{R}}(0)$. Strep ${ }^{2}$ (100), Amy $(77.8)$

location 3

Host: Pepper [King Athur]

Races: $\mathrm{P}_{3} \mathrm{~T}_{2}(20.0)$, $\mathrm{P}_{3} \mathrm{~J}_{2}$ (40.0) $\mathrm{P}_{\mathrm{I}}(40.0)$

$\mathrm{Cu}^{n}$ (100), $\mathrm{Zn}^{\mathrm{R}}$ (11,8), Strep" $(60.0), \mathrm{Amy}^{+}[60.0)$

Location 4

Host: Tomato (Heatwave)

Roces: $P_{2} T_{2}(5.9), P_{5} T_{2}(5.9), P_{8} T_{2}(82.4)$, UN (5.9)

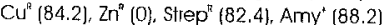

Location 5

Host: Tomato (Heatwave)

Races: $P_{5} T_{2}(66.7), P_{5} I_{4}(33.3)$

$\mathrm{Cu}^{\prime}(0), \mathrm{Zn}^{\mathrm{R}}$ (0), Sirep $\mathrm{p}^{\mathrm{R}}$ (100), Amy (66.7)

Location 6

Host: Tomato (Heatmaster)

Roces: $P_{2} T_{2}(5.0), P_{6} T_{2}(10.0), P_{5} T_{2}(40.0)$

$P_{6} T_{3}(40.0)$, UN [5.0]

$\mathrm{Cu}^{2}$ (40.0)، $\mathrm{Zn}^{\prime \prime}$ (80.0), Strep" (100), Amy (75.0)

Locotion?

Host: Tornato (Heatwave)

Race: $P_{0} T_{2}(100)$

$\mathrm{Cu}^{\mathrm{R}}$ (100), $\mathrm{Zn} \mathrm{n}^{\mathrm{R}}$ (0), Strep ${ }^{2}$ (100), Amy (100)

Location 8

Hosf: Tomato (Heatmaster)

Races: $P_{5} T_{2}(30.0), P_{5} T_{3}(6.1)$,

$P_{8} T_{2}(51.5), P_{B} T_{3}(3.0), U N\{9.1\}$

$\mathrm{Cu}^{\prime \prime}(39,4), \mathrm{Zn}^{2}(0)$, Stæep $^{n}$ (97.0), Amy' (69.7)

Localion?

Hos!: Tomato (Heatwave)

Races: $P_{2} T_{2}(6.9), P_{5} T_{2}(10.3), P_{3} T_{2}(82.3)$

$\mathrm{Cu}^{\mathrm{R}}$ (93.1), Zn $\mathrm{Zn}^{\mathrm{R}}$ (0), Strep ${ }^{\mathrm{q}}$ (79.5), Amy' (72.4)

Location 10

Host: Tomato (Heatwave)

Races: $\mathrm{P}_{2} \mathrm{~T}_{2}(5.9), \mathrm{P}_{3} \mathrm{~T}_{2}(17.6)$

$P_{T_{1}}\left(17\right.$ 8) $\mathrm{P}_{\mathrm{T}}(52.9) \cdot \mathrm{P}_{6} \mathrm{~T}_{3}(11.8)$

$\mathrm{Cu}^{\mathrm{n}}$ (35.3), Zn $\mathrm{Zn}^{\mathrm{i}}$ (0), Strep" (88.2), Amy $(41.2)$

Location 11

Host: Pepper [King Arthur]

Races: $P_{3} T_{2}(40.0), P_{6} T_{2}(60.0)$

$\mathrm{Cu}^{\mathrm{R}}(60.0), \mathrm{Zn}^{\mathrm{g}}(0)$, Strep $^{\mathrm{R}}(40.0), \mathrm{Amyy}^{+}(80.0)$

Location 12

Hosł: Tornato (Heatwave)

Races: $P_{3} T_{2}(5.0), P_{6} T_{2}(95.0)$

$\mathrm{Cu}^{\mathrm{A}}(95.0), 2 \mathrm{r}^{\mathrm{R}}(0), \mathrm{Sfrep}^{2}$ (85.0), Amy' $(85.0)$

Fig. 1. Distribution of races of Xanthomonas campestris pv. vesicatoria on Grenada, Antigua, and St. Lucia in the East Caribbean. 
differential pepper and tomato genotypes in locations infested only with incompatible races of $X$. campestris pv. vesicatoria. Sources of bacterial spot pepper resistance that could be deployed in the eastern Caribbean are gene $B s 2$ and/or gene $B s 1$, which are expected to restrict the bacterium at four of five locations in Antigua, three of four locations in Grenada, and the lone farm selected in St. Christopher. The quantitative bacterial spot resistance gene complex of Hawaii 7998 (22) also is predicted to control bacterial spot of tomato at one location in Grenada. The durability of these sources of resistance is, however, likely to be affected by the capacity of the bacterium to undergo mutation for race change in the field (17). Kousik et al. (15) proposed that durability of bacterial spot pepper resistance in the field can be improved significantly by planting mixtures of bacterial spot resistant and susceptible pepper genotypes as single crops in conjunction with the use of chemical sprays.

In the absence of sources of bacterial spot resistance that could be deployed, bactericides containing zinc offer promise for disease control since high frequencies of sensitivity to zinc were observed in populations of $X$. campestris pv. vesicatoria in the present study. The effectiveness of copper bactericides for bacterial spot control is likely to be limited, as only three of four locations on Grenada and one location each on St. Lucia and Antigua were infested predominantly with copper-sensitive strains of the bacterium. Two locations each in Antigua and Grenada were infested with strains of the bacterium sensitive to streptomycin, but the use of this bactericide for plant crop disease control is generally not allowed in the eastern Caribbean.

Races P2T1 and P3T2 in Antigua, P0T1 and P2T1 in St. Christopher, P5T2 and $\mathrm{P} 6 \mathrm{~T} 2$ in St. Lucia, and P1T2 and P6T2 in Grenada were among the most prevalent pathotypes detected in the present study, and they also were among the most aggressive on tomato on the respective islands (Tables 1 and 2). These races were similar to Barbadian P1 and T1 strains, which were most virulent on pepper and tomato fruits, respectively (18). Strains overcoming gene $B s 2$, however, appear to be of lower virulence than the other races detected in the present study since they were generally associated with the smallest lesions on tomato, notably in St. Lucia.

Table 3. Frequencies of strains resistant to copper, zinc, or streptomycin in populations of Xanthomonas campestris pv. vesicatoria from four East Caribbean islands

\begin{tabular}{lcccc}
\hline & & \multicolumn{3}{c}{ Percent resistant strains } \\
\cline { 3 - 5 } Country & Strains & Copper & Zinc & Streptomycin \\
\hline Antigua & 990 & 10.6 & 0 & 68.2 \\
St. Christopher & 138 & 8.7 & 0 & 62.3 \\
St. Lucia & 2,166 & 66.7 & 7.6 & 83.6 \\
Grenada & 1,740 & 41.4 & 2.0 & 62.3 \\
\hline
\end{tabular}

The detection of races of $X$. campestris pv. vesicatoria capable of overcoming gene $B s 2$ in the field is a fairly recent phenomenon $(12,13,18)$. Bacterial spot resistance encoded by gene $B s 2$ was expected to be durable since compatible races of the bacterium were hitherto undetected in the field (11). This expectation was supported by observations that races that overcame gene $B s 2$ resistance exhibited low multiplication rates under nonfield conditions, indicating that these strains may be naturally uncompetitive (11). Moreover, the corresponding avirulence gene $a v r B s 2$ was found to be conserved in many other phytopathogenic bacteria, thus raising prospects for the use of gene $B s 2$ for disease control in other plant genotypes (11). Reports of increasing numbers of field populations of races of $X$. implications for the use of this gene for disease control. Moreover, it appears that these races can become established and be quite damaging.

It is interesting that the spectrum and frequencies of $X$. campestris pv. vesicatoria races, as well as sensitivity of the bacterium to bactericides and its ability to hydrolyze starch, generally varied with geographical location in each country despite the small size of each island (Fig. 1). These variations probably reflect local edaphic and cultural factors or sources of inoculum.

Previous studies reported the presence of group A of $X$. campestris pv. vesicatoria in the Caribbean $(4,5)$. In the present study, only phenotypic characteristics generally associated with groups A and B of the bacterium were determined. Only strains of $X$. campestris pv. vesicatoria capable of overcoming gene $B S 2$ contained the $\beta$ protein. These strains also hydrolyzed starch but were unable to utilize cis-aconitate. These races of the bacterium generally resemble group B strains in these characteristics but were similar to group A strains by their inability to hydrolyze pectate. Similarly, a random sample of $X$. campestris pv. vesicatoria races, including $\mathrm{T} 1$, P0T1, P0T2, P1T1, P1T2, P2T2, P3T1, and P3T2, all of which contained the $\alpha$ protein and were unable to hydrolyze starch and pectate but oxidized cis-aconitate, resemble group A strains. There were no other detectable relationships between race types and the results of other tests, namely responses to copper, zinc, and/or campestris pv. vesicatoria that can overcome resistance encoded by gene $B s 2$ have streptomycin, conducted in the present study.

\section{ACKNOWLEDGMENTS}

This research was supported by grants from the United Nations Education, Scientific and Cultural Organization/United Nations Development Programme Project RLA/87/024 and Barclays Bank Development Fund in the Caribbean. I thank Cynthia Spooner for typing the manuscript and Marsha Atherley, Norma Samuels, Frederick Jones, Nymphia Edward, and Everest Ferguson for technical support.

\section{LITERATURE CITED}

1. Adaskaveg, J. E., and Hine, R. B. 1985. Copper tolerance and zinc sensitivity of Mexican strains of Xanthomonas campestris pv. vesicatoria, causal agent of bacterial spot of pepper. Plant Dis. 69:993-996.

2. Bender, C. L., Malvick, D. K., Conway, K. E., George, S., and Pratt, P. 1990. Characterization of PXV10A, a copper resistance plasmid in Xanthomonas campestris pv. vesicatoria. Appl. Environ. Microbiol. 56:170-175.

3. Bouzar, H., Jones, J. B., Minsavage, G. V., Stall, R. E., and Scott, J. W. 1994. Proteins unique to phenotypically distinct groups of Xanthomonas campestris pv. vesicatoria revealed by silver staining. Phytopathology 84:39-44

4. Bouzar, H., Jones, J. B., Stall, R. E., Hodge, N. C., Minsavage, G. V., Benedict, A. A., and Alvarez, A. M. 1994. Physiological, chemical, serological, and pathogenic analyses of a worldwide collection of Xanthomonas campestris pv. vesicatoria strains. Phytopathology 84:663-671.

5. Bouzar, H., Jones, J. B., Stall, R. E., Somodi, G. C., Kelly, R. O., and Daouzli, N. 1994 Phenotypic characterization of Xanthomonas campestris pv. vesicatoria strains from the Caribbean and Central America. (Abstr.) Phytopathology 84:1069.

6. Conover, R. A., and Gerhold, N. R. 1981 Mixtures of copper and maneb or mancozeb for control of bacterial spot of tomato and their compatibility for control of fungus diseases. Proc. Fla. State Hortic. Soc. 94:154156.

7. Cook, A. A., and Stall, R. E. 1982. Distribution of races of Xanthomonas vesicatoria pathogenic on pepper. Plant Dis. 66:388-389.

8. Hartman, G. L., and Yang, C. H. 1990. Occurrence of three races of Xanthomonas campestris pv. vesicatoria on pepper and tomato in Taiwan. Plant Dis. 74:252.

9. Hibberd, A. M., Stall, R. E., and Bassett, M. J. 1987. Different phenotypes associated with incompatible races and resistant genes in bacterial spot disease of pepper. Plant Dis. 71:1075-1078.

10. Jones, J. B., Stall, R. E., Scott, J. W., Somodi, G. C., Bouzar, H. and Hodge, N. C. 1995. A third tomato race of Xanthomonas campestris pv. vesicatoria. Plant Dis. 79:395-398.

11. Kearney, B., and Staskawicz, B. J. 1990. Widespread distribution and fitness contribution of Xanthomonas campestris avirulence gene $a v r$ Bs2. Nature (Lond.) 346:385-386.

12. Kousik, C. S., and Ritchie, D. F. 1995. Isolation of pepper races 4 and 5 of Xanthomonas campestris pv. vesicatoria from diseased peppers in Southeastern U.S. fields. Plant Dis. 79:540.

13. Kousik, C. S., and Ritchie, D. F. 1995. Characteristics of pepper bacterial spot pathogen races that overcome the $B S 2$ gene for resistance. (Abstr.) Phytopathology 85:1163.

14. Kousik, C. S., and Ritchie, D. F. 1996. Race shift in Xanthomonas campestris pv. vesicatoria within a season in field-grown pepper. Phytopathology 86:952-958. 
15. Kousik, C. S., Sanders, D. L., and Ritchie, D. F. 1996. Mixed genotypes combined with copper sprays to manage bacterial spot of bell peppers. Phytopathology 86:502-508.

16. Minsavage, G. V., Canteros, B. I., and Stall, R. E. 1990. Plasmid-mediated resistance to streptomycin in Xanthomonas campestris pv. vesicatoria. Phytopathology 80:719-723.

17. Minsavage, G. V., Dahlbeck, D., Whalen, M. C., Kearney, B., Bonas, U., Staskawicz, B. J., and Stall, R. E. 1990. Gene-for-gene relationships specifying disease resistance in Xanthomonas campestris pv. vesicatoria-pepper interactions. Mol. Plant-Microbe Interact. 3:41-47.

18. O'Garro, L. W., and Tudor, S. 1994. Contribution of four races of Xanthomonas campestris pv. vesicatoria to bacterial spot in
Barbados. Plant Dis. 78:88-90.

19. Pohronezny, K., Stall, R. E., Canteros, B. I., Kegley, M., Datnoff, L. E., and Subramanya, R. 1992. Sudden shift in the prevalent race of Xanthomonas campestris pv. vesicatoria in pepper fields in southern Florida. Plant Dis. 76:118-120.

20. Ritchie, D. F., and Dittapongpitch, V. 1991. Copper- and streptomycin-resistant strains and host differentiated races of Xanthomonas campestris pv. vesicatoria in North Carolina. Plant Dis. 75:733-736.

21. Schaad, N. W., and Stall, R. E. 1988. Xanthomonas. Pages 81-94 in: Laboratory Guide for Identification of Plant Pathogenic Bacteria. 2nd ed. N. W. Schaad, ed. American Phytopathological Society, St. Paul, MN.

22. Scott, J. W., and Jones, J. B. 1989. Inheritance of resistance to foliar bacterial spot of tomato incited by Xanthomonas campestris pv. vesi catoria. J. Am. Soc. Hortic. Sci. 14:111-114.

23. Stall, R. E., Beaulieu, C., Egel, D., Hodge, M C., Leite, R. P., Minsavage, G. V., Bouzar, H., Jones, J. B., Alvarez, A. M., and Benedict, A A. 1994. Two genetically diverse groups of strains are included in a pathovar of Xantho monas campestris. Int. J. Syst. Bacteriol. 44:47-53.

24. Stall, R. E., Loschke, D. C., and Jones, J. B. 1986. Linkage of copper resistance and avirulence loci on a self-transmissible plasmid in Xanthomonas campestris pv. vesicatoria. Phytopathology 76:240-243.

25. Ward, H. P., and O'Garro, L. W. 1992. Bacterial spot of pepper and tomato in Barbados. Plant Dis. 76:1046-1048. 